\title{
Anna Szwed-Walczak, Obraz wroga Polski we współczesnej politycz- nej prasie narodowej
}

Wydawnictwo Uniwersytetu Marii Curie-Skłodowskiej, Lublin 2019, 492 ss.

https://doi.org/10.19195/1643-0328.29.10

Dzieje polskiej formacji nacjonalistycznej, nierozerwalnie związanej z historią narodu i państwa polskiego, budziły zainteresowanie wielu środowisk naukowych. Narodowa Demokracja doczekała się bogatej i różnorodnej literatury. Po 1989 roku można zauważyć rozwój badań nad dziejami polskiej myśli politycznej oraz znaczny wzrost zainteresowania badaczy szeroko pojętą "prawą stroną” sceny politycznej. Badania nad polskim ruchem nacjonalistycznym zintensyfikowały się zwłaszcza w latach dziewięćdziesiątych XX wieku i na początku XXI wieku. Dzieje i myśl polityczna Narodowej Demokracji stały się przedmiotem zainteresowania badaczy w różnych ośrodkach naukowych w Polsce. Intensywne studia były prowadzone w ośrodkach akademickich w Gdańsku, Katowicach, Krakowie, Lublinie, Łodzi, Poznaniu, Szczecinie, Toruniu, Warszawie, Wrocławiu. Rezultatem były liczne monografie, rozprawy, opracowania zbiorowe, artykuły przyczynkarskie, studia i szkice. Stosując różnorodne kryteria badawcze, o wielu aspektach praktyki i myśli politycznej Narodowej Demokracji pisali liczni przedstawiciele nauk humanistycznych. Badacze polskiego nacjonalizmu przyjmowali różne układy badań - najczęściej chronologiczne bądź problemowe. Zasadniczym przedmiotem ich zainteresowania była szeroko rozumiana problematyka narodowa, która tworzyła niezbędną osnowę każdej z prac poświęconych ruchowi narodowemu.

Postęp w badaniach doprowadził do odkrywania nowych obszarów penetracji naukowej. Praca Anny Szwed-Walczak wydana nakładem Wydawnictwa Uniwersytetu Marii Curie-Skłodowskiej, Lublin 2019 (monografia ukazała się na rynku wydawniczym w marcu 2020 roku), przedstawia obraz wroga we współczesnej politycznej prasie narodowej. Monografia jest opracowaniem ważnym, w istotnym stopniu wzbogacającym historiografię najnowszych dziejów Polski. Nie można jej pominąć w badaniach dziejów ruchu nacjonalistycznego i jego idei politycznych w Polsce, a także dziejów prasy politycznej. Praca Anny Szwed-Walczak jest istotną i potrzebną pozycją na polu badań nad komunikowaniem politycznym i dziejami obozu narodowego. Książka powstała na gruncie dotychczasowych zainteresowań badawczych autorki dotyczących myśli politycznej, komunikowania politycznego i prasy Narodowej Demokracji. Opracowanie 
wypełnia istotną lukę badawczą i przyczynia się do poznania zasad komunikowania politycznego XX i XXI wieku.

Badania nad czasopiśmiennictwem nie tylko umożliwiają analizę warsztatu dziennikarskiego, technicznej procedury wytwarzania czasopism, lecz także eksplorację procesu komunikowania i odkrycie jego funkcji. Współczesną polityczną prasę narodową można określić jako zbiór periodyków nawiązujących do ideologii narodowodemokratycznej, powstałych po transformacji ustrojowej. Za cezurę początkową uznano rok przemian transformacyjnych wraz $\mathrm{z}$ ich skutkami dla obozu narodowego, a także pierwszymi próbami zjednoczenia działaczy narodowych w ramach jednego ugrupowania. Cezurą końcową jest 25 maja 2014 roku, czyli dzień wyborów do Parlamentu Europejskiego, w których środowiska neoendeckie zarejestrowały Komitet Wyborczy Wyborców Ruch Narodowy, odwołujący się w nazwie do inicjatywy młodego pokolenia narodowców. W omawianej monografii ukazano proces budowy narodowego rynku prasowego w Polsce po 50 latach zakazu legalnej działalności środowisk politycznych propagujących ideologię narodową. Przedmiot badań został zawężony do kategorii obrazu wroga na łamach prasy upowszechniającej narodową myśl polityczną.

Jak stwierdziła autorka monografii, sukces Marszu Niepodległości organizowanego w Warszawie od 2010 roku przez Młodzież Wszechpolską i Obóz Narodowo-Radykalny umożliwił tworzenie struktur organizacyjnych Ruchu Narodowego na terenie całej Polski i dał nadzieję środowiskom narodowym na zbudowanie liczącej się organizacji politycznej. W niniejszej publikacji narodowcami nazwano członków bądź sympatyków narodowych ugrupowań politycznych, którzy za fundament ideowy uznali myśl polityczną Romana Dmowskiego, Zygmunta Balickiego i Jana Ludwika Popławskiego.

Ogromną zaletą omawianej książki jest jej przejrzysta i logiczna struktura. Już na wstępie autorka wyjaśniła główne pojęcia użyte w monografii. Poprawność ogólnych sformułowań świadczyła o stosowaniu właściwego słownictwa naukowego. Autorka umiejętnie połączyła informacje obecne w historiografii z drobiazgowymi ujęciami analitycznymi.

Celem badań była rekonstrukcja obrazu wroga Polski w prasie narodowej po 1989 roku. Książka składa się z pięciu rozdziałów ujętych w układzie problemowym. Pozwoliło to na klarowne przedstawienie obrazu wroga we współczesnej prasie narodowej. W rozdziale pierwszym ukazano okresy istotne dla prasy narodowej, koncentrując uwagę na syntetycznym przedstawieniu ewolucji narodowego rynku prasowego (z uwzględnieniem jego uwarunkowań w danym okresie) i opisaniu czołowych organów prasowych. W rozdziale drugim skoncentrowano się na genezie wroga Polski oraz na ukazaniu tych obszarów, w których wróg się przejawiał. W trzeciej części został przedstawiony wynik analizy periodyków pod względem rozpoznania wroga, jego zdefiniowania i stosowanego nazewnictwa. Zwrócono uwagę na rolę stereotypów w myśleniu politycznym, ale też na ich kulturowe uwarunkowania. W czwartym rozdziale zaprezentowano wskazanych przez narodowców wrogów wewnętrznych Polski, wyszczególnionych pod względem kryterium ideologiczno-światopoglądowego. W ostatnim rozdziale natomiast wskazano wrogów zewnętrznych. Opracowanie ma charakter interdyscyplinarny. Zastosowano 
metody badawcze charakterystyczne dla nauk o polityce oraz medioznawstwa. Wykorzystano metody: porównawczą, genetyczną, ilościową analizę zawartości prasy i jakościową analizę treści.

Wyjątkowo skrupulatnie została wykorzystana literatura przedmiotu, zwłaszcza najnowsze opracowania naukowe. Wykorzystane zostały opracowania bezpośrednio związane $\mathrm{z}$ badanym problemem, ale sięgnięto także po opracowania przyczynkarskie, $\mathrm{w}$ tym publikacje w języku angielskim. Dysertację cechuje więc solidna, kompletna, odpowiednio dobrana podstawa źródłowa oraz rzetelność i zarazem ostrożność w pozyskiwaniu wiedzy źródłowej. Nie ulega wątpliwości, że rozległa i wyczerpująca podstawa źródłowa umożliwiła pełną realizację zamierzeń badawczych.

Autorka przeanalizowała około 1000 artykułów z 22 periodyków. Praca opiera się głównie na źródłach pierwotnych. Przedmiotem badań były periodyki narodowe powstałe po 1989 roku: „Bastion”, numery specjalne „Gazety Warszawskiej”, „Głos Narodu: Pisma Stronnictwa Narodowego”, „Młody Narodowiec”, „My, Nowe Pokolenie”, „Myśl.pl”, „Myśl Polska”, „Nowa Myśl Polska”. Wykorzystane zostały również akty prawne, programy polityczne, deklaracje ideowe, mowy parlamentarne, mowy wyborcze, artykuły prasowe, pisma polityczne i publicystyczne, broszury ideowe, materiały statystyczne, materiały propagandowe w postaci druków ulotnych, jak afisze, ulotki polityczne. Dogłębnie została przeanalizowana grupa źródeł memuarystycznych w postaci pamiętników czy relacji spisywanych na bieżąco lub retrospektywnie. Autorka sięgnęła także po twórczość literacką, utwory beletrystyczne, krytykę literacką. Uwzględnienie problematyki utworów literackich w toku badania skomplikowanego zjawiska, jakim jest komunikowanie polityczne, niewątpliwie zasługuje na podkreślenie. Tak szeroka podstawa źródłowa umożliwiła sformułowanie ważnych wniosków. Medialny obraz wroga Polski we współczesnej prasie narodowej był wynikiem narodowodemokratycznej tradycji rozważań o wrogu, geopolitycznego położenia Polski, oceny doświadczeń historycznych narodu polskiego oraz bieżących wydarzeń politycznych. Wróg miał więc wymiar historyczny, był odwieczny lub czasowy.

Ogólne wrażenie jasności i prostoty tekstu wynika z jednoznaczności myśli wyrażonej w czytelnym i klarownym języku. Toku narracji nie zakłócają cytaty, których liczba i celność doboru świadczy o harmonijnym ustaleniu proporcji między wiedzą źródłową i komentarzami autorskimi. Na uwagę zasługują bogactwo i różnorodność przypisów: wykorzystane zostały zarówno bibliograficzne, źródłowe, słownikowe, jak i dygresyjne, polemiczne oraz odsyłające.

Ogólnie rzecz ujmując, mamy do czynienia z przedsięwzięciem o solidnych podstawach. Autorka dokonała niezmiernie skrupulatnej kwerendy, obejmującej spektrum zróżnicowanych materiałów i źródeł, co nadaje rozprawie charakter gruntownej i wielopłaszczyznowej analizy. Wywody są klarowne i przekonujące. Mamy do czynienia z gruntownie przemyślaną pracą. Rozważania autorki są rzeczowe i precyzyjne, zawsze dobrze udokumentowane.

Anna Szwed-Walczak przygotowała monografię Obraz wroga Polski we współczesnej politycznej prasie narodowej z niebywałą starannością. Uwagę czytelnika zwracają zarów- 
no bogactwo zgromadzonych faktów, jak i drobiazgowe dokumentowanie prezentowanych zjawisk. Opracowanie zasługuje na uwagę czytelników ze względów poznawczych i dydaktycznych. Dużą zaletą pracy jest komunikatywność treści. Książka ta powinna stać się lekturą obowiązkową studentów politologii, dziennikarstwa, kulturoznawstwa i wszystkich osób zainteresowanych omawianą problematyką.

Poczynione w niniejszej recenzji refleksje żadną miarą nie oddają w pełni zawartości książki przygotowanej przez Annę Szwed-Walczak. Omawiana publikacja w przystępny sposób odsłania czytelnikowi wagę, złożoność i wieloaspektowość podejmowanych problemów. Należy ją uznać za jedną ze znaczących w odniesieniu do badanej tematyki. W pełni zadowala czytelnika stylistyczno-redakcyjna strona rozprawy. Książka zwraca uwagę dbałością o stronę estetyczną: starannie zaprojektowana okładka, dbałość o każdy detal zachęcają czytelnika do sięgnięcia po nią. Należy dodać, że publikacja została opatrzona indeksem osób, wykazem skrótów, wykazem tabel i wykresów. 